Volume $4 \cdot$ Nomor $1 \cdot$ Oktober 2020

Pege (Hal.) : 102 - 114

(C) Universitas Pamulang

JL.Surya Kencana No.1 Pamulang, Tangerang Selatan - Banten

website. :

Telp. (021) 7412566, Fax (021) 7412491

http://www.openjournal.unpam.ac.id/index.php/JPK

Email : jurnalmarketing.unpam@gmail.com

\title{
The Influence Of Marketing Strategy and Brand Community On MSME Sales In South Tangerang City
}

\author{
Sam Cay ${ }^{1}$; Jeni Irnawati ${ }^{2}$ \\ Universitas Pamulang Email: dosen02207@unpam.ac.id ; dosen02228@unpam.ac.id
}

\begin{abstract}
The purpose of this study was to determine the appropriate marketing strategy to increase sales volume at MSME South Tangerang, to find out which Brand Community could improve purchasing decisions at MSME South Tangerang and to find out marketing strategies and Brand Community that could increase sales at MSME South Tangerang. The method used for this research is the mix methods method. The population in this study is the population of all MSMEs in the South Tangerang area, and the sample we use is the MSMEs who are members of a Tangsel community called Tangsel Berkibar which number more than 500 MSME members. Because the population is too large, namely more than 100 people and limited time and personnel, the number of samples taken by the researcher is 50 respondents in that population. Where according to Arikunto (2002: 112) if the population is more than 100 then $5-10 \%$ or $20-30 \%$ of the population is taken. The statistical analysis used was the classical assumption test and multiple linear regression using the SPSS 26 program. The results obtained were that there was a partially significant influence between E-commerce Marketing on the Sales of South Tangerang MSMEs, there was a partially significant effect between Brand Community and the Sales of Tangerang MSMEs. South and there is a significant influence simultaneously between E-commerce Marketing and Brand Community on the Sales of South Tangerang MSMEs.
\end{abstract}

Keywords: E-commerce Marketing; Brand Community; Sales

\section{A. INTRODUCTION}

The development of MSMEs or Small and Medium Enterprises in Indonesia continues to develop due to continued economic growth. This development certainly requires SMEs to be more creative and innovative in formulating effective marketing strategies. An MSME will find it difficult to develop if the business actor does not know how to market a product effectively. Especially in the use of information and communication technology in the trade sector, it has developed very rapidly through a number of very significant changes in the form of digitalization, capital mobility and liberalization. Indonesia is also one of the countries with the largest number of MSME sectors, where the Ministry of Cooperatives and Small and Medium Enterprises (MSMEs) has recorded 59.2 million and around 8\% of MSME players have used online platforms to market their products, and based on data from the Cooperative Office and UKM Provisinsi Banten in 2018, in South Tangerang City 
there are 9,582 UMKM players. The rapid development of technology makes business people also have to be quick to adapt to these changes, one form of technology is social media. Indonesia is one of the countries with the largest level of social media users in the world. According to the latest We Are Social report, in 2020 there are 175.4 million Internet users in Indonesia. Compared to the previous year, an increase of $17 \%$ or 25 million Internet users in this country. The report also notes that 338.2 million Indonesians currently use cell phones. In addition, the data is no less interesting, there are 160 million active users of social networks (medsos). Compared to 2019, this year there was an increase of 10 million people who are active in social media.so currently a lot of MSMEs have used social media in marketing.

\section{B. LITERATURE REVIEW}

Marketing Strategy according to Sofjan Assauri (2013: 15), "Marketing Strategy is a series of goals and objectives, policies and rules that give direction to the company's marketing efforts from time to time, at each level and its references and allocations, especially as a response. companies in the face of an ever-changing competitive environment and conditions ". Meanwhile, "According to Kotler and Armstrong (2008), the definition of the marketing strategy is a marketing logic where the business unit expects to create value and benefit of the consumer".

Brand Community according to Kotler and Keller (2012: 275) also provides an understanding of the brand community as a special community of consumers and / or employees who are identified and have activities focused on one particular brand. Meanwhile, according to Muniz and O'Guin (2004: 413): "Brand communication is something special, a relationship that has no boundaries, based on a set of social relationship structures among brand lovers".

Understanding brand by (Kotler 1991; 442 in Keller, 1993) "can be interpreted as a brand name, term, sign, symbol or design or a combination of everything that has the objective to identify the goods and services of a single seller or group of sellers and differentiate them from the competition".

Understanding Branding, branding plays an important role in service companies because a strong brand will increase consumer confidence in unseen purchases. Branding in service can help consumers by assuring them of a uniform level of service quality. Branding also helps service providers by elevating services above the commodity level to differentiate services relative to competing brands. "Bharadwaj et al. (1993) in (Krishnan, Hartline, 2001) also argue that branding is more important for services than for goods because of the complexity faced by consumers in purchasing services, and the unique characteristics of services".

Understanding Brand Image, a positive consumer image of a brand allows consumers to make purchases. A good brand forms the basis for a positive corporate image. "According to Kotler (2005: 629) image or image is a set of beliefs, ideas and impressions that a person has on an object". Image is also defined as a vision as a whole or an object and a series of mental images and feelings that result

Sales according to Amin Wijaya (2011: 92) "Sales are an income transaction of goods or services sent by customers in exchange for cash for an obligation to pay". Meanwhile, according to Moekijat (2011: 488), Sales is an activity that aims to find buyers, influence and provide directions so that buyers can adjust their needs with the production offered and enter into agreements regarding prices that are favorable for both parties. 


\section{RESEARCH METHODOLOGY}

The method used for this research is descriptive quantitative method. The population in this study is the population of all MSMEs in the South Tangerang area, and the sample we use is the MSMEs who are members of a Tangsel community called Tangsel Berkibar which number more than 500 MSME members. Because the population is too large, namely more than 100 people and limited time and personnel, the number of samples taken by the researcher is 50 respondents in that population. Where according to Arikunto (2002: 112 ) if the population is more than 100 then $5-10 \%$ or $20-30 \%$ of the population is taken. The statistical analysis used was classical assumption test and multiple linear regression using SPSS 26.

\section{RESULT AND DISCUSSION}

1. Validity Test

The validity test is intended to test the statment on each item of the question in the questionnaire is valid or not to process the validity test of researchers using SPSS Version 26. Here are the results of validation test for e-commerce marketing variables.

Table 4.1

Validity Test Result Based on E-commerce Marketing Variables ( $\left.X_{1}\right)$

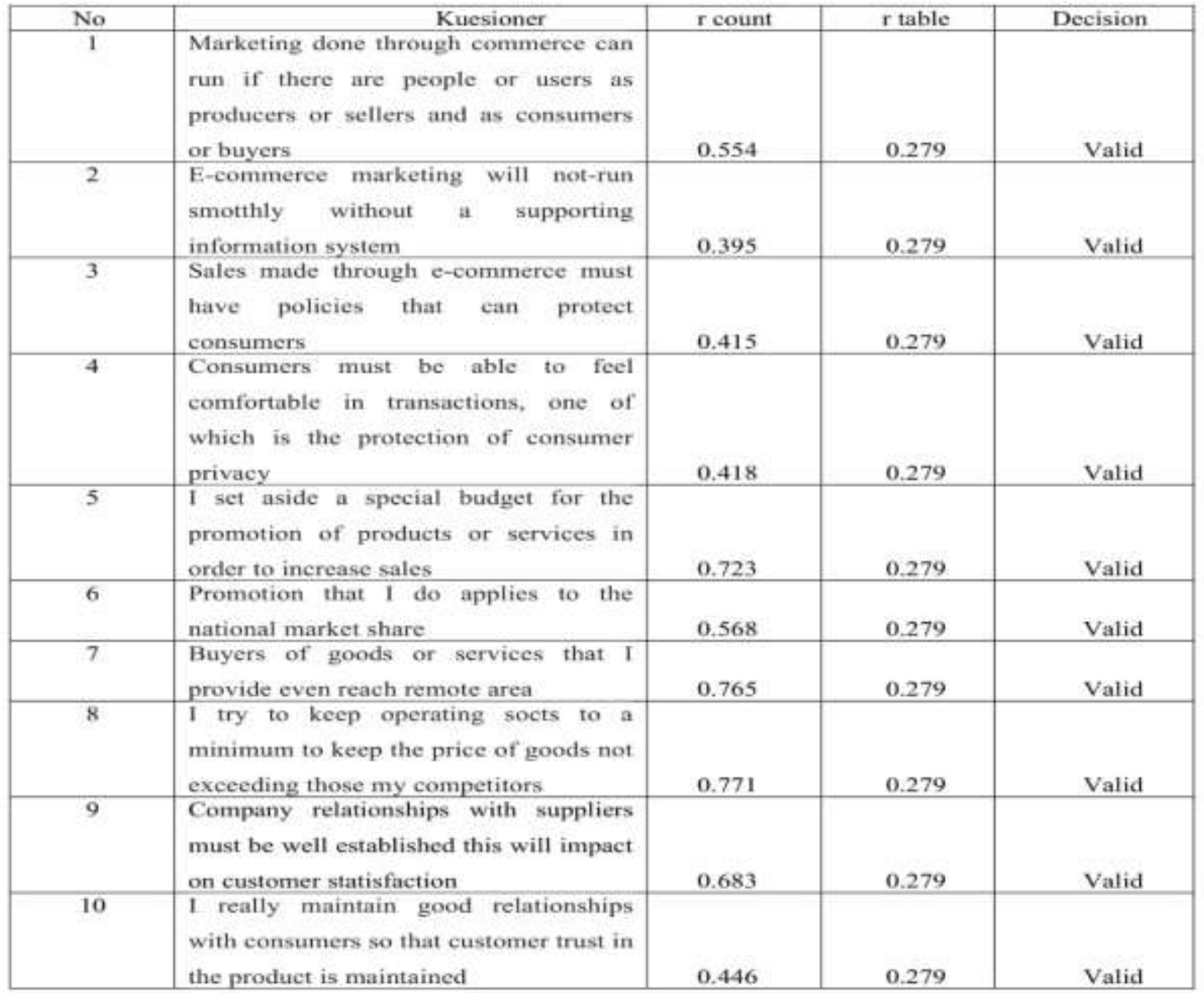


Based on the table data above, the e-commerce marketing variable $(X 1)$ obtained the value of $r$ count $>r$ table $(0.279)$, thus all questionnaire items were declared valid. For this reason, the questionnaire used is feasible to be processed as research data.

Table 4.2

\section{Validity Test Results based on Brand Community}

\begin{tabular}{|c|c|c|c|c|}
\hline No & Kuesioner & r count & $\mathrm{r}$ table & decision \\
\hline 1 & $\begin{array}{l}\text { Your involvement in providing information about the sale of } \\
\text { MSMEs in South Tangerang is very important for the progress of } \\
\text { all community members }\end{array}$ & 0.476 & 0.279 & Valid \\
\hline 2 & $\begin{array}{l}\text { Activeness in providing information about the world of } \mathrm{e} \text { - } \\
\text { commerce is very useful for mutual progress }\end{array}$ & 0.513 & 0.279 & Valid \\
\hline 3 & $\begin{array}{l}\text { The activeness of various experiences is very important for the } \\
\text { progress of fellow community members }\end{array}$ & 0.522 & 0.279 & Valid \\
\hline 4 & $\begin{array}{l}\text { Active in communicating among the community online is very } \\
\text { important }\end{array}$ & 0.544 & 0.279 & Valid \\
\hline 5 & $\begin{array}{l}\text { Activeness in providing comments on ideas and suggestions for } \\
\text { products to be sold is very important }\end{array}$ & 0.430 & 0.279 & Valid \\
\hline 6 & $\begin{array}{l}\text { Sales made throught a community must be profitable to both } \\
\text { sellers and buyers }\end{array}$ & 0.362 & 0.279 & Valid \\
\hline 7 & $\begin{array}{l}\text { In a community maintaining friendship is very important, one way } \\
\text { for example by holding meetings between community members }\end{array}$ & 0.701 & 0.279 & Valid \\
\hline 8 & $\begin{array}{l}\text { Fellow com munity members occasionally give special prices to } \\
\text { community mere is importmbers so that the product can be } \\
\text { recognized by all members }\end{array}$ & 0.589 & 0.279 & Valid \\
\hline 9 & $\begin{array}{l}\text { Fellow community members will usually provide feedback to the } \\
\text { seller so that there is improvement in terms of product quallity }\end{array}$ & 0.714 & 0.279 & Valid \\
\hline 10 & Every manufacturer expects positive feedback on merchandise & 0.515 & 0.279 & Valid \\
\hline
\end{tabular}

Based on the table data above, the Brand Community variable (X2) obtained the value of $r$ count $>r$ table (0.279), thus all questionnaire items were declared valid. For this reason, the questionnaire used is feasible to be processed as research data. 
ISSN NO. (PRINT) 2598-0823, (ONLINE) 2598-2893

Table 4.3

Validity Test Results based on Sales

\begin{tabular}{|l|l|c|c|c|}
\hline No & Kuesioner & r count & r table & Decision \\
\hline 1 & $\begin{array}{l}\text { After joining a sales community has } \\
\text { increased }\end{array}$ & 0.533 & 0.279 & Valid \\
\hline 2 & $\begin{array}{l}\text { Sales that I do through e-commerce really } \\
\text { help me in sales }\end{array}$ & 0.556 & 0.279 & Valid \\
\hline 3 & $\begin{array}{l}\text { Sales that I do through e-commerce really } \\
\text { help me increase sales }\end{array}$ & 0.416 & 0.279 & Valid \\
\hline 4 & $\begin{array}{l}\text { After joining a community my sales have } \\
\text { increased }\end{array}$ & 0.386 & 0.279 & Valid \\
\hline 5 & $\begin{array}{l}\text { The sales that I make must earn a } \\
\text { reasonable profit }\end{array}$ & 0.461 & 0.279 & Valid \\
\hline 6 & $\begin{array}{l}\text { Sales that I make must provide a profit } \\
\text { commensurate with the capital spent }\end{array}$ & 0.467 & 0.279 & Valid \\
\hline 7 & $\begin{array}{l}\text { After joining a sales community I did earn } \\
\text { more than before joining }\end{array}$ & 0.724 & 0.279 & Valid \\
\hline 8 & $\begin{array}{l}\text { After joining a community and sales using } \\
\text { e-commerce sales has increased }\end{array}$ & 0.629 & 0.279 & Valid \\
\hline 9 & $\begin{array}{l}\text { E-commerce is very helpfull in making } \\
\text { buying and selling transactions }\end{array}$ & 0.709 & 0.279 & Valid \\
\hline 10 & $\begin{array}{l}\text { Selling goods or services using e- } \\
\text { commerce is very efficient and effective }\end{array}$ & \begin{tabular}{l} 
Valid \\
\hline
\end{tabular} \\
\hline
\end{tabular}

Based on the table data above, the Sales variable $(Y)$ obtained the value of $r$ count $>r$ table (0.279), thus all questionnaire items were declared valid. For this reason, the questionnaire used is feasible to be processed as research data. 


\section{Reliability Test}

The results of the reliability test in this study were carried out using the SPSS software for Windows Version 26, which results as follows:

\section{Tabel 4.4}

\section{The Result of The Reliability test of The Independen and Dependent Variables}

\begin{tabular}{|l|c|c|c|}
\hline \multirow{2}{*}{$\begin{array}{c}\text { Variabel } \\
\text { E-commerce Sales (X1) }\end{array}$} & $\begin{array}{c}\text { Cronbatch } \\
\text { Alpha }\end{array}$ & $\begin{array}{c}\text { Standar } \\
\text { Cronbatch Alpha }\end{array}$ & Decision \\
\cline { 2 - 4 } & 0.762 & 0.600 & Reliabel \\
\hline Brand Community (X2) & 0.727 & 0.600 & Reliabel \\
\hline Sales $(Y)$ & 0.732 & 0.600 & Reliabel \\
\hline
\end{tabular}

Source: Primary Dara is Processed, 2020

Based on the test results in the table above shows that variables of E-commerce Marketing (X1), Brand Community (X2) and Sales (Y) are declared reliable, this is evidenced by each variable having a Chronbath Alpha value greater than 0.600 .

\section{Classic Asumption Test}

The classical assumption test is used to determine the accuracy of the data, or the meaning of the relationship between the independent variables and the dependent variable so that the results of the analysis can be interpreted more accurately, efficiently, and avoid the weaknesses that occur because there are still symptoms of classic assumptions or feasible or not data. which is used continued as research data. The tests were performed using the SPSS Version 26 program. In this study comprises the classical assumption of normality test, multicollinearity, autocorrelation, and heteroscedasticity test.

\section{a. Normality Test}

The normality test in this study used the Kolmogorov-Smirnov Test with the terms of the significance $\alpha>0.050$. The test results with the Kolmogorov-Smirnov normality are as follows:

Table 4.5

\section{The Result of The Normality Test with The Kolmogorov-Smirnov Test}

\begin{tabular}{|c|c|c|c|c|c|c|}
\hline \multicolumn{7}{|c|}{ Tests of Normality } \\
\hline & Statistic & df & Sig. & Statistic & Df & Sig. \\
\hline Penjualan $(Y)$ & .088 & & $.200^{\circ}$ & .974 & 5 & .337 \\
\hline
\end{tabular}

$\star$. This is a lower bound of the true significance.

a. Lilliefors Significance Correction

Source: Primary Dara is Processed, 2020

Based on the above table test results, a significance value of $\alpha=0.200$ is obtained where the value is greater than the value of $\alpha=0.050$ or $(0.200>0.050)$. Thus, the assumption of the distribution of the equation in this test is normal. 
The normality test is also carried out using a probability plot graph where the residual variables can be detected by looking at the distribution of residual points following the direction of the diagonal line, and this is in accordance with the results of the distribution diagram processed with SPSS Version 26 as shown below:

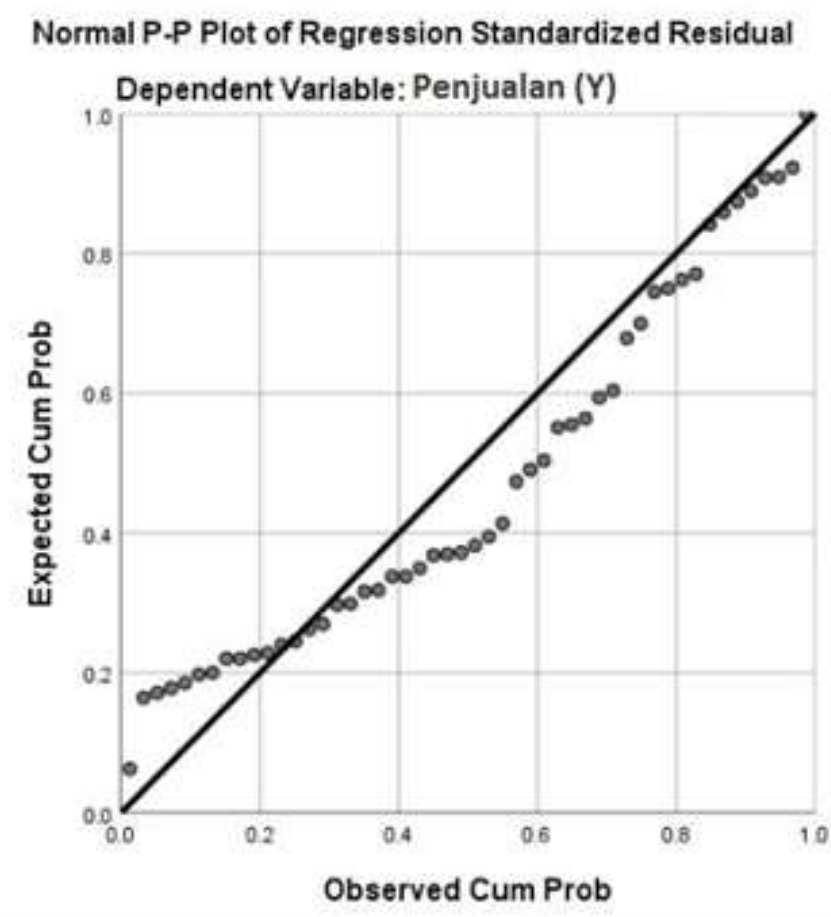

b. Multicollinearity Test

Table 4.6

Multicollinearity Test Result with The Collinearity Statistic Sales as The Dependen Variable

\begin{tabular}{|l|c|c|}
\hline \multirow{2}{*}{ Variabel } & \multicolumn{2}{|c|}{ Colinerity Statistics } \\
\cline { 2 - 3 } & Tolerance & VIF \\
\hline E-commerce Marketing (X1) & 0.656 & 1.525 \\
\hline Brand Community (X2) & 0.656 & 1.525 \\
\hline
\end{tabular}

Source: Primary Dara is Processed, 2020

Based on the results of the multicollinearity test in the table above, the tolerance value for each independent variable is obtained, namely e-commerce marketing of 0.656 and Brand Community of 0.656 , where both values are less than 1 , and the value of the Variance Inflation Factor (VIF) for the E-commerce Marketing variable. of 1.525 and the Brand Community of 1.525 where the value is less than 10 . Thus the regression model did not have multicollinearity. 
c. Autocorrelation Test

\section{Tabel 4.7}

Autocorrelation Test Results with Durbin Watson

\begin{tabular}{|c|c|c|c|c|c|}
\hline \multirow[b]{2}{*}{ Model } & \multicolumn{4}{|c|}{ Model Summary ${ }^{\text {b }}$} & \multirow[b]{2}{*}{ Durbin-Watson } \\
\hline & $\mathrm{R}$ & R Square & $\begin{array}{l}\text { Adjusted } \\
\text { R Square }\end{array}$ & $\begin{array}{l}\text { Std. Error of } \\
\text { the Estimate }\end{array}$ & \\
\hline 1 & $.719^{\mathrm{a}}$ & .517 & .496 & 2.638 & 1.657 \\
\hline
\end{tabular}

a. Predictors: (Constant), Brand Community (X2), E-commerce Marketing (X1)

b. Dependent Variable: Sales $(Y)$

Source: Primary Dara is Processed, 2020

Based on results of the table above, this regression model does not have autocorrelation, this is evidenced by the Durbin-Watson value of 1.657 which is between the interval 1,550 - 2,460.

d. Heteroscedaticity Test

Tabel 4.8

Heteroscedaticity Test Result with Glejser Test

\begin{tabular}{|c|c|c|c|c|c|}
\hline \multirow[b]{3}{*}{ Model } & \multicolumn{5}{|c|}{ Coefficients $^{a}$} \\
\hline & \multicolumn{2}{|c|}{$\begin{array}{l}\text { Unstandardized } \\
\text { Coefficients }\end{array}$} & \multirow{2}{*}{$\begin{array}{c}\text { Standardized } \\
\text { Coefficients } \\
\text { Beta } \\
\end{array}$} & \multirow[b]{2}{*}{$t$} & \multirow[b]{2}{*}{ Sig. } \\
\hline & B & Std. Error & & & \\
\hline 1 (Constant) & 4.569 & 2.706 & & 1.689 & .098 \\
\hline E-commerce Marketing $\left(X_{1} 1\right)$ & -.116 & .077 & -.265 & -1.506 & .139 \\
\hline Brand Community (X2) & .046 & .079 & .102 & .579 & .566 \\
\hline
\end{tabular}

a. Dependent Variable: RES2

Source: Primary Dara is Processed, 2020

Based on the test results in the table above, the Glejser test model on the Ecommerce Marketing variable (X1) obtained a significance probability value (Sig.) Of 0.139 and Brand Community (X2) obtained a significance probability value (Sig.) Of 0.566 where both are significance values. (Sig.)> 0.05. Thus the regression model on this data does not have heterosxasticity disorders, so this regression model is suitable for use as research data. 


\section{Simple Regression Analysis}

Results of regression test study aims to determine how much influence the variables $\mathrm{X} 1$ and $\mathrm{X} 2$ to variable $\mathrm{Y}$. In this study, e-commerce marketing (X1) and Brand community $(\mathrm{X} 2)$ on sales $(\mathrm{Y})$ either partially or simultaneously.

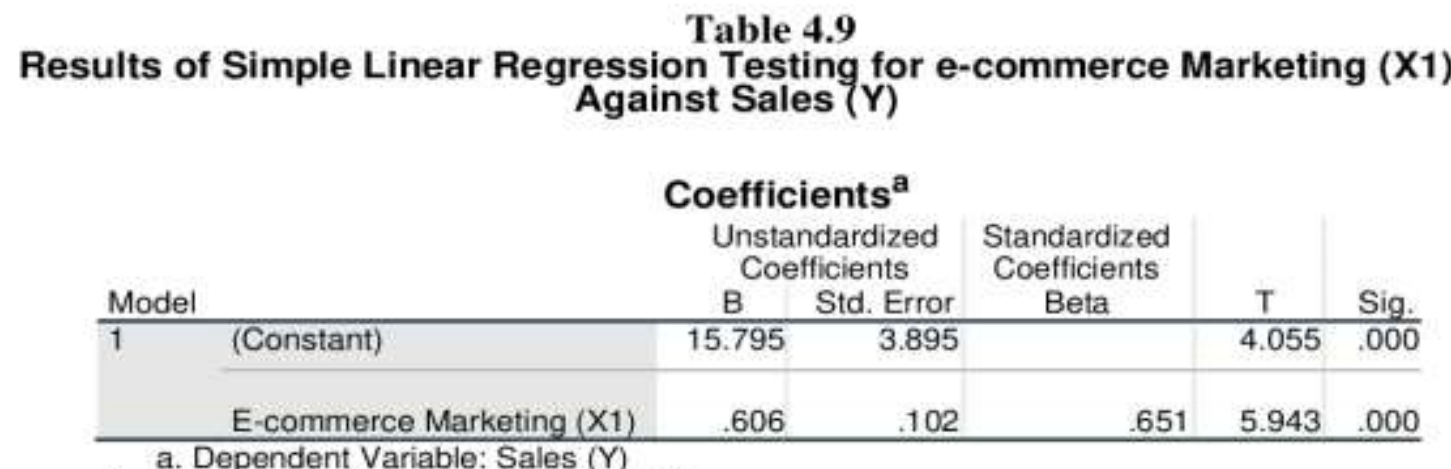

Source: Primary Dara is Processed, 2020

Table 4.10

\section{Multiple Regression Test Results E-commerce Marketing Variables (X1) and Brand Community (X2) Against Sales (Y)}

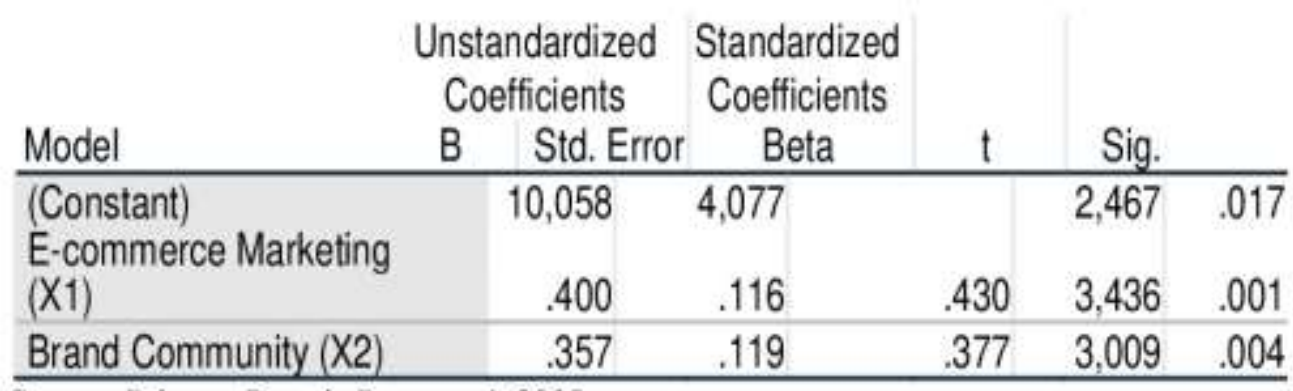

Source: Primary Dara is Processed, 2020

Correlation coefficient analysis is intended to determine the level of strength of the relationship between the independent variable and the dependent variable. The results of data processing are as follows:

Table 4.11

Results of Partial Correlation Coefficient Analysis Between E-commerce Marketing (X1) Against Sales (Y)

\begin{tabular}{|c|c|c|c|}
\hline & Correla & $\begin{array}{l}\text { tions } \\
\text { E-commerce } \\
\text { marketing }(X 1)\end{array}$ & $\begin{array}{r}\text { Sales } \\
(Y)\end{array}$ \\
\hline E-commerce & & & \\
\hline \multirow{2}{*}{ Marketing (X1) } & Pearson Correlation & 1 & $651^{\cdots}$ \\
\hline & Sig. (2-tailed) & & .000 \\
\hline \multirow{2}{*}{ Sales $(Y)$} & Pearson Correlation & $.651^{\cdots}$ & 1 \\
\hline & Sig. (2-tailed) & .000 & \\
\hline
\end{tabular}

**. Correlation is significant at the 0.01 level (2-tailed).

b. Listwise $\mathrm{N}=50$

Source: Primary Dara is Processed, 2020 
ISSN NO. (PRINT) 2598-0823, (ONLINE) 2598-2893

Table 4. 12

Results of Correlation Coefficient Analysis Partially Between Brand Community (X2) Against Sales (Y)

\begin{tabular}{|c|c|c|c|}
\hline \multicolumn{4}{|c|}{ Correlations $^{b}$} \\
\hline & & $\begin{array}{r}\text { Brand } \\
\text { Community } \\
(\mathrm{X} 2)\end{array}$ & (Y) ${ }^{\text {Sales }}$ \\
\hline \multirow[t]{2}{*}{ Brand Community (X2) } & Pearson Correlation & 1 & $.629^{*}$ \\
\hline & Sig. (2-tailed) & & .000 \\
\hline \multirow[t]{2}{*}{ Sales $(Y)$} & Pearson Correlation & $.629^{\star *}$ & 1 \\
\hline & Sig. (2-tailed) & .000 & \\
\hline
\end{tabular}

Table 4.13

The Results of Simultaneous Correlation Coefficient Analysis Between e-commerce Marketing (X1) and Brand Community (X2) Against Sales (Y)

\begin{tabular}{|c|c|c|c|c|}
\hline \multirow[b]{2}{*}{ Model } & \multicolumn{3}{|c|}{ Model Summary } & \multirow[b]{2}{*}{$\begin{array}{c}\text { Std. Error of the } \\
\text { Estimate }\end{array}$} \\
\hline & $\mathrm{R}$ & R Square & $\begin{array}{c}\text { Adjusted R } \\
\text { Square }\end{array}$ & \\
\hline$\overline{1}$ & $.719 a$ & .517 & .496 & 2,638 \\
\hline
\end{tabular}

Determination coefficient analysis intended to determine the percentage strength of the relationship between the independent variable and the dependent variable either partially or simultaneously), in this study the variable E-commerce Marketing (X1) and Brand Community (X2) on penjulan (Y). The following is the calculated coefficient of determination that is processed using SPSS Version 26, as follows:

Table 4.14

Results of Partial Determination Coefficient Analysis Between e-commerce Marketing (X1) and Sales (Y)

\begin{tabular}{l|c|c|c|c} 
& & \multicolumn{2}{c}{ Model Summary } \\
Model & R & R Square & $\begin{array}{c}\text { Adjusted R } \\
\text { Square }\end{array}$ & \multicolumn{2}{c}{$\begin{array}{c}\text { Std. Error of the } \\
\text { Estimate }\end{array}$} \\
\hline 1 & .651a & .424 & .412 & 2,851 \\
\hline
\end{tabular}

a. Predictors: (Constant), E-commerce Marketing (X1)

Source: Primary data processed, 2020 
Table 4.15

Results of Partial Determination Coefficient Analysis Between Brand Community (X2) Against Sales (Y)

Model Summary

\begin{tabular}{|c|c|c|c|c|}
\hline \multicolumn{5}{|c|}{ Model Summary } \\
\hline Model & $\mathbf{R}$ & R Square & $\begin{array}{l}\text { Adjusted R } \\
\text { Square }\end{array}$ & $\begin{array}{l}\text { Std. Error of the } \\
\text { Estimate }\end{array}$ \\
\hline 1 & $.629 a$ & .396 & .383 & 2,920 \\
\hline
\end{tabular}

a. Predictors: (Constant), Brand Community (X2)

Source: Primary data processed, 2020

Table 4.16

Results of the Simultaneous Determination Coefficient Analysis Between

E-commerce Marketing (X1) and Brand Community (X2) Against Sales (Y)

\begin{tabular}{|c|c|c|c|c|}
\hline \multirow[b]{2}{*}{ Model } & \multicolumn{3}{|c|}{ Model Summary } & \multirow[b]{2}{*}{$\begin{array}{l}\text { Std. Error of the } \\
\text { Estimate }\end{array}$} \\
\hline & $\mathrm{R}$ & R Square & $\begin{array}{c}\text { Adjusted R } \\
\text { Square }\end{array}$ & \\
\hline 1 & $.719 a$ & .517 & .496 & 2,638 \\
\hline
\end{tabular}

a. Predictors: (Constant), Brand Cpmmunity (X2), E-commerce Marketing (XI)

Source: Primary data processed, 2020

Hypothesis testing of variables E-commerce Marketing (X1) and Brand Community $(X 2)$ on Sales $(Y)$ was carried out by using the t test (partial test). In this study, the $5 \%$ $(0.05)$ significance criteria were used by comparing t count with t table, namely as follows:

Table 4.17

Hypothesis Test Results (t test) E-commerce Marketing Variables (X1) Against Sales ( $Y$ )

\begin{tabular}{|c|c|c|c|c|c|}
\hline Model & $\begin{array}{c}\text { Coeffi } \\
\text { Unstar } \\
\text { Coe } \\
\text { B }\end{array}$ & $\begin{array}{l}\text { cientsa } \\
\text { hdardized } \\
\text { fficients } \\
\text { Std. Error }\end{array}$ & $\begin{array}{c}\text { Standardized } \\
\text { Coefficients } \\
\text { Beta }\end{array}$ & $t$ & Sig. \\
\hline (Constant) & 15,795 & 3,895 & & 4,055 & .000 \\
\hline E-commerce Marketing (X1) & .606 & .102 & .651 & 5,943 & .000 \\
\hline
\end{tabular}

Table 4.18

Result of $t$ Test for Brand Community Variable (X2) Against Sales (Y)

\begin{tabular}{|c|c|c|c|c|c|}
\hline \multirow[b]{3}{*}{ Model } & \multicolumn{5}{|c|}{ Coefficients ${ }^{a}$} \\
\hline & \multicolumn{2}{|c|}{$\begin{array}{l}\text { Unstandardized } \\
\text { Coefficients }\end{array}$} & \multirow{2}{*}{$\begin{array}{c}\text { Standardized } \\
\text { Coefficients } \\
\text { Beta }\end{array}$} & \multirow[b]{2}{*}{$t$} & \multirow[b]{2}{*}{ Sig. } \\
\hline & B & Std. Error & & & \\
\hline (Constant) & 16,191 & 4,058 & & 3,990 & .000 \\
\hline Brand Community (X2) & .596 & .106 & .629 & 5,606 & .000 \\
\hline
\end{tabular}

a. Dependent Variable: Sales $(Y)$

Source: Primary Dara is Processed, 2020 
To test the effect of variables of e-commerce Marketing and Brand Community simultaneously on Sales at South Tangerang MSMEs, the F statistical test (simultaneous test) was carried out with $5 \%$ significant In this study, file $5 \%(0.05)$ significance criteria were used, namely comparing the calculated $F$ value with the $F$ table with the following conditions:

Table 4.19

Hypothesis Results (Test F) Simultaneously Between Marketing E-commerce (X1) and Brand Community (X2) Against Sales (Y)

\begin{tabular}{|c|c|c|c|c|c|c|}
\hline \multirow[b]{2}{*}{ Model } & & \multicolumn{2}{|c|}{ ANOVAa } & \multirow[b]{2}{*}{$\begin{array}{l}\text { Mean } \\
\text { Square }\end{array}$} & \multirow[b]{2}{*}{$\mathrm{F}$} & \multirow{3}{*}{$\frac{\text { Sig. }}{.000}$} \\
\hline & & $\begin{array}{l}\text { Sum of } \\
\text { Squares }\end{array}$ & Df & & & \\
\hline 1 & Regression & 350,206 & 2 & 175,103 & 25,154 & \\
\hline & Residual & 327,174 & 48 & 6,961 & & \\
\hline & Total & 677,380 & 50 & & & \\
\hline
\end{tabular}

a. Dependent Variable: Sales $(Y)$

b. Predictors: (Constant), Brand Community (X2), E-commerce Sales (X1)

Source: Primary Dara is Processed, 2020

\section{E. CONCLUSION}

Based on the descriptions in the previous chapters, and from the results of the analysis and discussion of the effect of e-commerce marketing and brand community sales, as follows: e-commerce marketing has a significant effect on sales with the regression equation $Y=15.795+0.606 \mathrm{X} 1$, the correlation coefficient value is 0.651 means that the two variables have a strong level of relationship with a determination coefficient of $42.4 \%$. Hypothesis test obtained $t$ count $>t$ table or $(5,943>2,011)$. Thus $\mathrm{H}^{\circ}$ is rejected and $\mathrm{H}_{1}$ is accepted, it means that there is a significant influence between e-commerce marketing on the sales of South Tangerang MSMEs. Brand Community has a significant effect on sales with the regression equation $Y=16.191+0.596 \times 2$, the correlation coefficient value is 0.629 , meaning that both have a strong relationship level with a determination coefficient of $39.6 \%$. Hypothesis test obtained $t$ count $>t$ table or $(5.606>2.011)$. Thus, $\mathrm{H}^{\circ}$ is rejected and $\mathrm{H}_{2}$ is accepted, meaning that there is a significant influence between Brand Community and MSME Sales in South Tangerang. E-commerce marketing and Brand Community have a significant effect on sales with the regression equation $Y=10.058+0.400 X 1+0.357 X 2$. The correlation coefficient values obtained for 0.719 , meaning that the dependent and independent variables have a strong influence level of relationship with a coefficient of determination or simultaneous effect of $51.7 \%$ while the remaining $48.3 \%$ is influenced by other factors. Hypothesis testing obtained the value of $F$ count> $F$ table or $(25,154>2,800)$. Thus $\mathrm{H}^{\circ}$ is rejected and $\mathrm{H}^{3}$ is accepted. Simultaneous significant influence between ecommerce marketing and Brand Community on the Sales of MSMEs in South Tangerang. 


\section{REFERENCE}

Amin Widjaja Tunggal, 2011, Understanding the Concept of Economic Value Added (EVA) and Value Based Management (VBM), Harvarindo.

Anwar. 2012, Excipients in pharmaceutical characterization and application preparations, Dian Rakyat Publisher, Jakarta.

Arikunto, S. 2010. Research procedures are a practical approach. Jakarta, copyright.

Assauri, Sofjan. 2013. Marketing Management. Jakarta: Rajawali Press.

Basu Swastha. 2009. Modern Marketing Management. (2nd edition), yogyakarta: Liberty Publisher-Yogyakarta

Berry, L. L. (2000). Cultivating service brand equity. Journal of the Academy of Marketing Science, 28 (1), 128-137

Ghozali, Imam, 2013, Multivariate Analysis Application with the IBM SPSS 21 update PLS Regression program, Semarang, Diponegoro University publishing body.

Gujarati, Damodar N and Dawn. Porter 2015. Basics of econometrics Issue 5, book 2. Jakarta, Salemba Empat.

Keller, K.L. (2013). Strategic Brand Management: Building, Measuring, and ManagingBrand Equity, Global Edition. Pearson

Kotler, and Keller. 2012. Marketing Management. 12. Jakarta Edition: Erlangga.

Moeheriono, 2012, Competency-based Performance Measurement, Jakarta, Raja Grafindo Persada.

Lesmana, R., \& Ayu, S. D. (2019). Pengaruh Kualitas Produk Dan Citra Merek Terhadap Keputusan Pembelian Kosmetik Wardah PT Paragon Tehnology And Innovation. Jurnal Pemasaran Kompetitif, 2(3), 59-72.

Lesmana, R. (2015). analisis strategi pemasaran untuk meningkatkan penjualan perumahan green river city bekasi (study kasus di pt. artha bangun pratama) (Doctoral dissertation, Universitas Pamulang).

Lesmana, R., Widodo, A. S., \& Sunardi, N. (2020). The Formation of Customer Loyalty From Brand Awareness and Perceived Quality through Brand Equity of Xiaomi Smartphone Users in South Tangerang. Jurnal Pemasaran Kompetitif, 4(1), 1-12.

Sugiyono, 2017. Quantitative, qualitative and R\&D research methods, Bandung, Alfabeta.

Sutrisno Hadi \& Sugiyono. 2016. Educational Research Methods with Quantitative Approaches, Qualitative, and R \& D. Bandung: Alfabeta

Sutarman, A., \& Lesmana, R. (2019, January). Analisis Keputusan Pembelian Konsumen dari Sisi Normtif dan Informatif Pada Supermarket Giant Pamulang, Tangerang Selatan. In PROCEEDINGS (Vol. 1, No. 1).

Turban, E., et al. Social Commerce, New York: Springer 2015.

Wahyu Srisadono. 2018. E-commerce Company Strategy to Build Community Brand in Social Media to Increase Sales Turnover. Journal of Communication Libraries, Vol. 1 No. 1 (2018), http://journal.moestopo.ac.id/index.php/pustakom/article/view/552, pages 167-179..

https://selular.id/2019/03/top-10-e-commerce-di-indonesia-2018/Penulisan dan penyusunan 